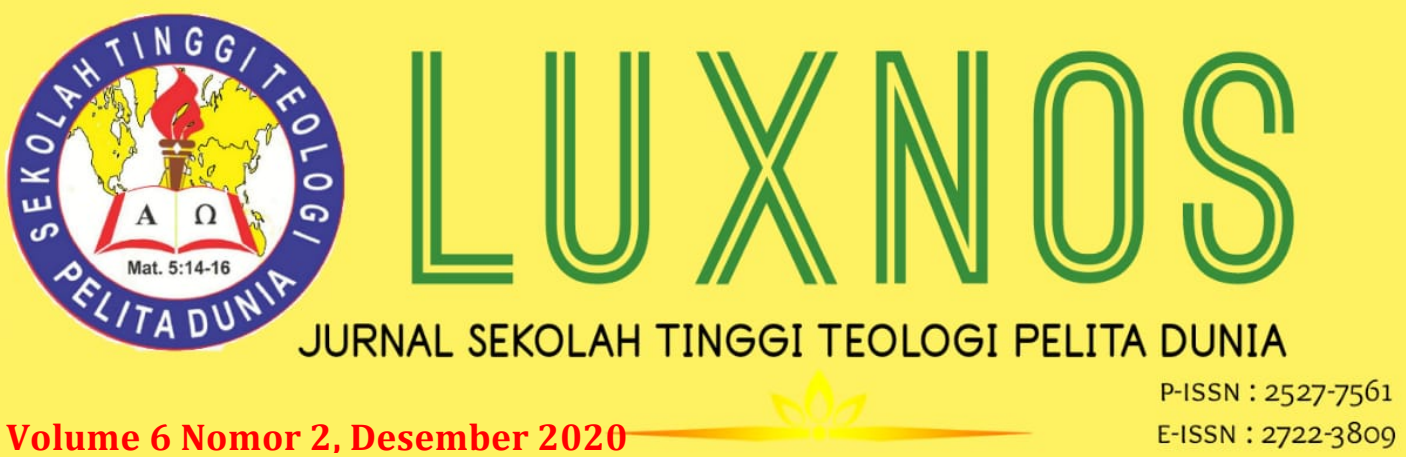

\title{
Ketika Covid -19 Menyerbu Taman Didaskalos
}

\author{
Yonas Muanley \\ STT IKSM Santosa Asih \\ ymuanley@gmail.com
}

\begin{abstract}
This study aims to reveal the negative and positive sides of the spread of Covid-19 which does not rule out the possibility of entering the theological high school campus which in this article uses a theological technical term, namely taman didaskalos. Taman didaskalos is a technical term used to refer to the place where the activities of didaskalos (teachers / lecturers and prospective teachers) take place, namely the Theology College campus, especially the Sekolah Tinggi Teologi IKSM Santosa Asih. The method used is a qualitative research method using domain taxonomic data analysis. The theory used is the study of Covid-19 and didaskalos which is based on a number of theoretical-theological truths about the two concepts studied, namely Covid and Didaskalos. The finding was that the didaskalos, especially the didaskalos candidates, saw Covid-19 as an enemy, which is why didaskalos comply with health protocols on campus. Meanwhile, Covid-19 as a friend still requires in-depth thinking about Covid-19.
\end{abstract}

Keywords: Covid-19, Taman, Didaskalos

\begin{abstract}
Abstrak: Penelitian ini bertujuan untuk mengungkapkan sisi negative dan positif dari penyebaran Covid-19 yang tidak menutup kemungkinan dapat memasuki kampus sekolah tinggi teologi yang di dalam artikel ini menggunakan istilah teknis teologis yakni taman didaskalos. Taman didaskalos adalah istilah teknis yang dipakai untuk merujuk pada tempat berlangsungnya kegiatan para didaskalos (guru/dosen dan calon guru) yaitu kampus Sekolah Tinggi Teologi khususnya Sekolah Tinggi Teologi IKSM Santosa Asih. Metode yang dipakai yakni metode penelitian kualitatif dengan menggunakan analisis data taksonomi domain. Teori yang digunakan yakni kajian tentang Covid-19 dan didaskalos yang didasarkan pada sejumlah kebenaran teoritik-teologis tentang dua konsep yang diteliti yaitu Covid dan didaskalos. Temuannya yakni para didaskalos khususnya calon didaskalos memandang Covid-19 sebagai musuh, itulah sebabnya para didaskalos mematuhi protokoler kesehatan di kampus. Sementara Covid-19 sebagai kawan masih memerlukan pemikiran yang mendalam tentang Covid-19.
\end{abstract}

Kata Kunci: Covid-19, Taman, Didaskalos 


\section{Pendahuluan}

Penelitian tentang Covid-19 telah dilakukan oleh beberapa rekan teologis dan mereka menempatkan Covid-19 dalam paradigma teologi bencana. Hal ini wajar saja, namun penulis tidak menggunakan pendekatan tersebut. Hal ini menegaskan bahwa ada unsur lain yang penulis hendak sampaikan dalam penelitian ini yakni 'Covid sebagai musuh/lawan dan kawan. ${ }^{1}$ Pokok ini mesti dipahami secara hati-hati agar tidak menimbulkan kesalah pahaman akan istilah covid-19 sebagai musuh dan kawan. Untuk itu pokok ini akan dijelaskan secara khusus dalam pembahasan ini.

Selain penjelasan di atas, perlu juga penjelasan tentang kata didaskalos. Kata didaskalos bukan bahasa Indonesia melainkan bahasa Yunani. Lalu mengapa pakai bahasa Yunani dan bukan kata yang dipakai di Indonesia? Ya sebenarnya memang demikian. Bila pakai bahasa Indonesia maka pakailah kata-kata Indonesia. Namun ada alasan teknis teologis untuk dua kata terakhir dalam judul artikel yaitu pada frasa taman didaskalos. Untuk memahami apa yang penulis maksudkan dengan taman didaskalos, tentu jawabanya penulis tuangkan dalam pembahasan.

Taman didaskalos sebagaimana yang disebutkan di atas, kini diserbu Covid-19. Serbuan ini mempengaruhi proses pembelajaran yang berlangsung di taman didaskalos. Namun penelitian ini tidak akan masuk dalam tataran masalah pendidikan dalam konteks pandemic covid-19. Cukup saja dalam pendahuluan ini penulis mengemukakan konsep tentang serbuan Covid-19 ke taman didaskalos yang dipandang sebagai alat Tuhan untuk batas kehidupan jasmani seseorang dan pada sisi lain serbuan ini menjadi alat Tuhan untuk membangunkan daya peta dan gambar Allah dalam diri para didaskalos Kristen dan pendidikan pada umumnya, bahkan siapapun yang memiliki peta dan gambar Allah dalam dirinya.

Penulis menyadari bahwa konsep Covid sebagai alat Tuhan pasti menimbulkan pro dan kontra. Konsep ini belum popular, yang popular adalah pandemic ini menjadi musuh bersama. Sementara Covid sebagai alat Tuhan untuk pengembangan kemampuan peta dan gambar Allah pasti ditolak oleh sebagian orang Kristen. Walaupun demikian, penulis memiliki kebebasan ilmiah untuk menyatakan Covid-19 sebagai alat Tuhan. Untuk topic ini, penulis akan membahasnya pada artkel ilmiah berikutnya termasuk masalah-masalah pendidikan yang disebabkan Covid-19 dalam efektivitas pembelajaran pada masa Corona-19.

1 Covid-19 sebagai musuh/lawan dan kawan merupakan istilah teknis teologis untuk menggambarkan pendekatan pemahaman teologis penulis dalam memandang Covid-19. Selain itu penulis meminjam alur berpikir Naratif dalam memandang Covid-19. Dalam penedetan Naratif biblika, ada tokoh sentral, kawan, musuh dll. 


\section{Metode Penelitian}

Metode penelitian merupakan salah satu bagian epistemology yang berupaya untuk mendapat pengetahuan yang benar tentang variable ${ }^{2}$ dan konsep ${ }^{3}$ yang diteliti. Pengetahuan yang benar disebut kebenaran. Kebenaran ini berhubungan dengan ilmu pengetahuan tertentu. Selanjutnya kebenaran ini dinamakan kebenaran ilmu pengetahuan.

Berdasarkan penjelasan di atas, perlu dibedakan kebenaran dalam teks suci seperti kebenaran yang memerdekakan dalam narasi Injil Yohanes. Kebenaran yang memerdekakan adalah kebenaran yang merujuk pada firman-Nya. Dalam firman-Nya tidak ada kebohongan. Oleh karena itu firman-Nya adalah kebenaran atau kebenaran langsung sedangkan kebenaran ilmu pengetahuan adalah kebenaran tidak langsung atau kebenaran melalui proses (baca: proses berpikir). Dengan kata lain, kebenaran melalui pengetahuan yang diperoleh dari hasil penelitian merupakan kebenaran proses berpikir. Kebenaran melalui proses berpikir jika benar maka kebenaran tersebut berasal dari Allah. ${ }^{4}$

Kebenaran yang dimaksudkan dalam pernyataan terakhir di atas dapat terjadi karena manusia memiliki logika natural. Menurut Yakub Tomatala, logika natural

${ }^{2}$ Variabel adalah konsep yang dapat diukur. Variabel biasanya dipakai dalam penelitian kuantitatif. Penelitian kuantitatif adalah penelitian menguji teori maka varaiabel adalah konsep yang dapat diukur atau memiliki atribut. Misalnya Kesaksian Alkitab tentang Sorga tidak dapat dilakukan pengukuran, yang dapat diukur adalah pemahaman jemaat tentang Sorga. Maka Sorga mesti dijadikan sebagai variable penelitian dengan rumusan variable seperti "Tingkat Pemahaman Warga Jemaat A Tentang Sorga. Kategori tingkat pemahaman itu diberi ukuran yaitu Sangat mengerti (5), Mengerti (4), Cukup Mengerti (3) Kurang Mengerti (2), Tidak Mengerti (1). Biasanya penelitian demikian ada dalam penelitian yang menggunakan metologi penelitian Kuantitatif, para peneliti berusaha merumuskan defenisi pribadi tentang pokok yang diteliti. Bagian ini disebut dalam bahasa Inggris dengan construct yang dalam penelitian selalu disebut pendapat peneliti tentang variable yang diteliti atau pemikiran peneliti yang dikomunikasikan kepada orang lain. Bagian ini dijadikan menjadi definisi konseptual dan operasional yang memiliki sejumlah indicator yang kemudian dijadikan sebagai instrument penelitian. Instrumen ini kemudian disebarkan kepada responden dan setelah diisi, kemudian diolah dengan analisis statistik. Hasilnya olah data ini memberi pengethuan yang benar tentang pokok yang diteliti. Pengetahuan yang benar adalah persesuaian antara pengetahuan dan objek penelitian. Tentang definisi peneliti yang dalam bahasa Inggris disebut Construct Lih. Sasmoko, Metode Penelitian (Jakarta: UKI Press, 2004), 46. Sedangkan Nur Indriantoro dan Bambang Supomo, Metodologi Penelitian Bisnis (Yogyakarta: BPFE Yogyakarta, 2002), 37

3 Konsep. Sebenarnya konsep dan variable sama artinya. Namun untuk keperluan penelitian dibedakan. Varaibel adalah konsep yang dapat diukur, dan dikenal dalam penelitian kuantitatif, sedangkan konsep tidak dapat diukur. Untuk konsep biasanya ada dalam penelitian kualitatif. Misalnya Rumah Gereja Kecil, Rumah Gereja Besar. Ini konsep dan merupakan pernyataan kualitatif. Penelitian kualitatif hendak mendapatkan data secara kualitatif atau natural sehingga yang diutamakan adalah proses dalam mendapatkan hasil. Sedangkan dalam penelitian kuantitatif, yang diutamakan adalah hasil (uji teori) maka sering proses tidak diperhatikan secara baik. Untuk referensi kualitatif dapat dibaca dalam Andreas Subagyo, Pengantar Riset Kuantitatif dan Kualitatif Termasuk Riset Teologi dan Keagamaan (Bandung: Kalam Hidup, 2004), 52

${ }^{4}$ Arthur F. Holmes, Segala Kebenaran adalah Kebenaran Allah (Surabaya: Momentum, 2009), 59 
adalah kemampuan manusia untuk berpikir sesuai kemampuan berpikir bawaannya. ${ }^{5}$ Kemampuan berpikir ini kemudian dibentuk menjadi kemampuan berpikir ilmiah dengan berbagai interaksi social dan teologis pada jenjang pendidikan akademis. Selanjutnya dalam penelitian ini penulis menggunakan metode penelitian kualitatif dengan analisis data taksonomi domain 6 yang dalam penelitian ini dikembangkan dalam domain calon didaskalos dan didaskalos. Analisis ini akan menghasilkan kebenaran rasional dan empiris natural atas topic yang diteliti.

\section{Hasil dan Pembahasan}

Hasil yang dimaksud dalam pokok ini yaitu hasil penelitian dan pembahasan atas hasil tersebut. Namun sebelum melakukan pemaparan tentang hasil penelitian dan pembahasan, penulis mengemukan kajian teori berkenaan dengan Coronavirus (Covid19) dan Didaskalos. Setelah itu, dikemukakan pemaparan hasil penelitian dan pembahasan.

\section{Kajian Teori}

\subsection{Pengertian Virus dan Corona Virus ( Covid-19)}

Penjelasan tentang virus penting karena kata ini digandeng dengan Corona-19. Di Indonesia, ada penggunaan frasa 'virus corona', sedangkan dalam salah satu bahasa Internasional yaitu bahasa Inggris disebut Coronavirus. Secara etimologi (asal kata), virus berasal dari bahasa Latin, yang diberi arti benda beracun. ${ }^{7}$ Kemudian secara definisi, "virus adalah organisme yang dapat menginfeksi semua bentuk kehidupan, dari hewan ke tumbuhan hingga bakteri."8 Dalam arti kata virus sebagai benda beracun, untuk sebagian orang dapat menimbulkan kesulitan memahami virus sebagai benda beracun. Untuk itu arti kata virus sebagai benda beracun perlu dibantu lagi dengan rujukan lain untuk maksud memperjelas pengertian. Dalam wikipedia virus diartikan "mikroorganisme patogen yang menginfeksi sel makluk hidup." ${ }^{9}$ Dalam dua sumber ini menggunakan istilah yang berbeda, sumber yang pertama (Anwar Daud) menggunakan kata 'benda beracun' sementara sumber kedua (Wikipedia) menggunakan kata mikroorganisme patogen. Terhadap istilah yang kedua pasti belum familiar dalam diri warga didaskalos. Oleh karena itu perlu dilanjutkan lagi dengan penjelasan. Dalam sumber yang sama yaitu di Wikipedia terdapat penjelasan bahwa patogen berasal dari

\footnotetext{
5Yakob Tomatala, Pembimbing Logika Seni Berpikir Benar, Baik, Cermat, Cerdas, Cerdik, Jitu dan Unggul (Jakarta : Media Penerbit Kristen YT Leadership Foundation, 2008), 40

${ }^{6}$ Afrizal, Metode Penelitian Kualitatif Sebuah Upaya Mendukung Penggunaan Penelitian Kualitatif Dalam Berbagai Disiplin Ilmu (Jakarta: Raja Grafindo Persada, 2016), 182

7 Anwar Daud, dkk. Penanganan Coronavirus (Covid-19) Ditinjau dari Perspektif Kesehatan Masyarakat (Yogyakarta : Gosyen Publishing, 2020), 1

${ }^{8}$ Anwar Daud, dkk. Penanganan Coronavirus

9 Virus. https://id.wikipedia.org/wiki/Virus (Diakses tanggal 07/09 2020)
} 
bahasa Yunani yang artinya sebagai penyebab penyakit. Dalam konteks arti kata Patogen sebagai penyebab penyakit maka definisi "patogen adalah agen biologis yang menyebabkan penyakit pada inangnya. ${ }^{10}$ Sedangkan kata mikroorganisme merupakan penamaan lain atau sebutan lain dari kata patogen. ${ }^{11}$ Sampai disini kiranya episteme ${ }^{12}$ tentang virus yang dihubungkan dengan Corona sekiranya menjadi jelas.

Penjelasan di atas belum membahas pengertian secara utuh tentang Coronavirus-19. Beberapa sumber seperti situs alodokter menyatakan bahwa "Virus Corona atau severe acute respiratory syndrome corona virus 2 (SARS-CoV-2) adalah virus yang menyerang sistem pernapasan."13 Pada definisi ini, Corona Virus merupakan penyebab penyakit yang secara khusus berhubungan dengan pernapasan. Setiap mahkluk hidup yang bernafas, khususnya manusia ketika terinfeksi Virus Corona maka akan terjadi gangguan pernapasan ringan pada system pernapasan sampai pada gangguan paru-paru (infeksi paru-paru) dalam kategori infeksi paru-paru berat. Mereka yang terinfeksi virus Corona pada tingkat tertentu dapat berakibat kematian. ${ }^{14}$

\subsection{Didaskalos dan Taman Didaskalos}

Penggunaan kata didaskalos dalam artikel ini tentu didasarkan pada kitab suci yaitu Perjanjian Baru. Walaupun demikian artikel ini tidak berusaha memaparkan hasi eksegesis atas kata didaskalos yang dipakai dalam sejumlah ayat dalam Perjanjian Baru. Pokok ini menjadi bidang kajian rekan-rekan biblika. Hal yang hendak dikatakan disini yakni kata didaskalos yang dipakai dalam artikel ilmiah ini di ambil dari sebutan murid dan para pengikut Yesus bahkan orang-orang lain yang menyapa Yesus dengan kata Didaskalos.

Untuk rekonstruksi pengetahuan tentang didaskalos, penulis berusaha memaparkan kata ini dari sisi etimologi. Secara etimologi (asal kata), kata didaskalos berasal dari kata didasko (Yunani) yang memiliki arti mengajar ( Inggris: to teach). ${ }^{15}$ Mereka (orang) yang melakukan kegiatan mengajar disebut dengan kata Didaskalos. Dalam hal ini kata didaskalos memiliki arti teacher, master, director. ${ }^{16}$

${ }_{10}$ Patogen. https://id.wikipedia.org/wiki/Patogen (Diakses tanggal 08/09 2020)

${ }^{11}$ Patogen. https://id.wikipedia.org/wiki/Patogen (Diakses tanggal 08/09 2020)

12 Episteme merupakan kata Yunani Kuno dari kata epistamai yang memiliki arti mengetahui, memahami, mengenal. Kata ini merupakan istilah filosofis (berpikir radikal) untuk menemukan kebenaran. Bila dikenakan pada virus maka episteme virus pasti lebih luas dan dalam. Artinya tidak sebatas apa yang penulis ungkapkan dalam tulisan ini. Itu berarti penjelasan tentang virus barulah merupakan episteme virus yang belum mendalam dalam konteks kompetensi bidang virus. Tentu ini dijelaskan oleh mereka yang bergelut dalam dunia kesehatan. Untuk epeisteme silakan baca https://en.m.wikipedia.org/wiki/Episteme

${ }^{13}$ Virus Corona. https://www.alodokter.com/virus-corona (Diakses tanggal 08/09 2020)

${ }_{14}$ Virus Corona. https://www.alodokter.com/virus-corona (Diakses tanggal 08/09 2020)

${ }^{15}$ Didaskalos. $\quad$ https://www.blueletterbible.org/lang/lexicon/lexicon.cfm?t=kjv\&strongs=g1320 Diakses tanggal, 26 September 2020

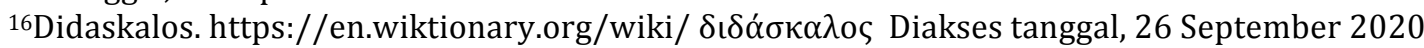


Kata didaskalos merupakan kata yang berasal dari bahasa Yunani. Dengan demikian dalam praktiknya, penelusuran mesti menghubungkan ke dunia Yunani Kuno. Artinya sebelum beberapa penulis Perjanjian Baru menggunakan kata didaskalos untuk menggambarkan kegiatan mengajar, khususnya pada Yesus maka perlu memperhatikan praktik didaktik dalam dunia Yunani Kuno. Penggunaan kata didaskalos dalam dunia Yunani Kuno sering dipakai untuk seorang guru. Jadi, kata didaskalos adalah sebutan untuk guru di Yunani Kuno. Walaupun demikian, dalam dunia modern seperti di sekolah Yunani-Latin pada abad ke-17 kata didaskalos dipakai untuk guru di sekolah persaudaraan. ${ }^{17}$ Beberapa sumber ini menegaskan bahwa kata ini digunakan dalam dunia Yunani Kuno tetapi juga dalam dunia modern seperti pada abad ke-17. Sampai pada pemaparan ini, episteme tentang didaskalos mesti berlanjut dengan sumber lain.

Dalam sumber yang lain seperti dalam Bible Tools, kata didaskalos diartikan dalam beberapa pengertian yaitu, didaskalos berarti seorang guru, kemudian di dalam Perjanjian Baru kata didaskalos berarti orang yang mengajar tentang hal-hal tentang Allah, dan tugas-tugas manusia seperti orang yang cocok mengajar, para guru agama Yahudi, mereka yang memiliki kekuasaan besar sebagai guru menarik orang banyak di sekitar mereka seperti Yohanes dan Yesus. ${ }^{18}$ Untuk sapaan Yesus sebagai didaskalos dapat diperhatikan dalam Perjanjian Baru.

Jadi, penggunaan kata didaskalos dalam Perjanjian Baru dipakai untuk menyapa Yesus dalam pekerjaan-Nya atau missinya melalui kegiatan mengajar. Secara nominal, kata didaskalos dipakai sebanyak 37 kali. ${ }^{19}$ Lalu kata didaskalos diterjemahkan dalam bahasa Indonesia dengan kata guru. Kata guru dipakai dalam Perjanjian Baru sebanyak 37 kali. ${ }^{20}$ Jumlah ini dapat dimaklumi karena menurut Philip Johnson, Injil Matius lebih banyak mendeskripsikan perkataan dan pengajaran Yesus dari pada injil Markus. Injil Markus memang memiliki narasi tentang pekerjaan Yesus dalam hal mengajar dalam jumlah yang relative sedikit bila dibandingkan dengan Injil Matius. ${ }^{21}$ Dengan demikian kata didaskalos dalam Perjanjian Baru merupakan sapaan yang diberikan oleh para murid dan orang-orang yang berjumpa dengan Yesus ketika Yesus melakukan pekerjaan-Nya di bumi (Palestina) selama beberapa tahun.

17 Didaskalos. https://encyclopedia2.thefreedictionary.com/Didaskalos. Diakses tanggal, 26 September 2020

18 Bible Tools. Strong's \#1320: didaskalos (pronounced did-as'-kal-os) from 1321; an instructor (genitive case

or specially):--doctor, master, teacher. https://www.bibletools.org/index.cfm/fuseaction/Lexicon.show/ID/G1320/didaskalos.htm. Diakses tanggal, 26 September 2020

${ }_{19}$ Didaskalos, https://alkitab.sabda.org/strong.php?id=1320 (Diakses tanggal, 29 Agustus 2020)

20 Didaskalos, https://alkitab.sabda.org/strong.php?id=1320 (Diakses tanggal, 29 Agustus 2020)

21 Philip Johnston, IVP Introduction to thr Bible. Pengantar untuk Mengenal Alkitab. Memahami Alkitab Berdasarkan Sejarah, Tema dan Penafsirannya (Bandung : Kalam Hidup, 2006), 244 
Bila penulis menyatakan bahwa kata didaskalos dalam Perjanjian Baru dipakai hanya menunjuk kepada Yesus, lalu bagaimana dengan sebelum dan sesudah Yesus?. Artinya apakah kata ini dipatenkan untuk salah satu pribadi. Tentu tidak demikian. Namun kualitas didaskalos dalam diri Yesus berbeda dengan didaskalos dalam diri para guru sebelum, semasa Yesus dan sesudah masa Yesus termasuk pengajar teologi di Indonesia. Dengan demikian kata didaskalos dapat dipakai untuk siapa saja yang melakukan kegiatan mengajar. Alasannya sebelum Yesus melakukan misinya melalui pengajaran, para guru Yunani juga melakukan didaskalos dan mereka disebut didaskalos, dan sesudah Yesus, para pengikut-Nya yang melakukan kegiatan mengajar dapat disapa dalam sebutan didaskalos.

Dalam Injil Matius 5:1-12 Yesus mengajar murid-murid dan orang banyak yang datang kepada-Nya. Teks-teks sesudahnya juga memberi informasi tentang kegiatan Yesus dalam hal mengajar. Demikian pula dalam Injil Markus walaupun jumlah informasi tentang Yesus sebagai pengajar lebih sedikit bila dibandingkan dengan Injil Matius

Bila dibandingkan kegiatan didaskalos dalam dunia Yunani maka jelaslah bahwa penggunaan kata didaskalos dalam Perjanjian Baru yang merujuk pada perbuatan Yesus dalam kegiatan pengajaran-Nya tentu berbeda dengan para didaskalos Yunani. Perbedaan itu terletak pada pesan yang disampaikan. Yesus menyampaikan pesan yang bersifat 'kebenaran langsung' sedangkan para didaskalos Yunani menyampaikan kebenaran melalui proses. Selanjutnya kata didaskalos dipakai untuk menyebut para pendidik (dosen dan calon guru dan calon pendeta) di sekolah tinggi teologi.

\subsection{Taman Didaskalos}

Kata 'taman didaskalos' merupakan istilah teknis ilmiah dalam konteks penulisan artikel ilmiah untuk keperluan jurnal Luxnos. Dengan demikian kata taman didaskalos yang penulis maksudkan yakni tempat para didaskalos (guru, dosen dan pendidik non formal) melakukan tugas mengajar dan belajar. Taman didaskalos dalam pengertian ini tentu merujuk pada kampus Sekolah Tinggi Teologi, ruang kuliah, ruang kelas, ruang katekisasi, ruang sekolah minggu, dll.

Ketika terjadi penyebaran virus Corona-19, ruang ruang kuliah menjadi sepi tanpa penghuni. Kuliah yang biasanya dilakukan secara konfensional (tatap muka langsung di ruang kelas maupun ruang kuliah) tiba-tiba dipaksa berubah. Bila tidak berubah maka Covid-19 menjadi musuh yang melenyapkan nyawa civitas akademika. Menyadari dampak buruk Covid-19, beberapa Sekolah Tinggi Teologi di Indonesia yang dalam artikel jurnal ini penulis sebut dengan 'taman didaskalos' melaksanakan perkuliahan secara online dalam satu sisi yaitu tatap muka online melalui video conference seperti pemanfaatan google meet, zoom dan lain lain. Dalam system ini, 
kuliah dilakukan melalui video sehingga para mahasiswa dan dosen dapat berinteraksi secara tatap muka yang disebut tatap muka dunia maya. Tatap muka langsung berubah menjadi tatap muka melalui media online. Corona-19 memaksa para didaskalos untuk mengubah metode bertemu dalam perkuliahan yang kini popular dengan mengajar melalui video konferens.

Ketika Covid-19 mewabah, Sekolah Tinggi Teologi mengizinkan para dosen dan mahasiswa mengubah ruang kuliah yang dapat dibawa ke mana-mana. Hal ini dimungkinkan karena kuliah virtual. Kuliah dapat dilaksanakan di rumah maupun di mana saja sejauh ada koneksi internet. Pernah penulis menyatakan pada tahun 2008, "dimana ada sinyal internet maka disana dilakukan pembelajaran. Ungkapan itu kini terjadi pada masa epidemic Covid-19.

Taman didaskalos yaitu kampus Sekolah Tinggi Teologi tidak kebal terhadap penyebaran virus corona-19. Tentu Sekolah Tinggi Teologi juga pasti diserang Virus Corona-19. Tidak ada perbedaan perlakuan Virus Corona-19 dengan mereka yang ada di Sekolah Tinggi Teologi. Semua manusia termasuk warga teologi seperti dosen dan mahasiswa berpotensi terinfeksi virus Corona (virus yang mengganggu sistem saluran pernapasan). Oleh karena Sekolah Tinggi Teologi dalam arti warganya berpotensi diserang virus corona-19 maka penulis merumuskan judul artikel "Ketika Virus Menyerang Taman Didaskalos". Salah satu bukti bahwa para didaskalos diserbu virus ini yaitu terlihat dari kesiapan warga didaskalos menggunakan masker, cuci tangan dan menjaga jarak social. Disini dapat dipahami bahwa virus gangguan sistem pernapasan dapat saja menimpa mereka-mereka yang berkarya di Sekolah Tinggi Teologi. Itulah sebabnya selain menggunakan masker, cuci tangan dan menjaga jarak aman, metode kuliahpun berubah. Jadi, apa yang terjadi ketika Covid menyerang taman didaskalos?

\section{Ketika Covid-19 Menyerbu Taman Didaskalos}

Apa yang dilakukan oleh para didaskalos ketika Virus Corona-19 menyerbu taman Didaskalos. Ada beberapa konsep yang mempengaruhi tindakan berikut ini.

\subsection{Corona Virus-19 Sebagai Musuh Manusia Secara Universal}

Virus Covid-19 tentu menjangkit manusia dan dalam kadar tertentu dapat mendatangkan bahaya bagi kehidupan pasien yang terjangkit virus ini. Dalam Jurnal penyakit dalam Indonesia menyatakan bahwa sekitar tanggal 18 - 29 Desember 2019 penyebaran virus ini menjangkit lima pasien, kemudian tanggal 31 Desember 2019 sampai 3 Januari 2020 penyebaran virus ini meningkat sehingga pasien yang mengalami Covid-19 bertambah menjadi 44 orang. Dalam kurun waktu tidak sampai satu bulan, virus ini menyebar ke berbagai propinsi di China dan beberapa Negara lainnya seperti Thailand, Jepang dan Korea Selatan. Dengan demikian nama virus ini 
yakni Penyebaran penyakit ini kemudian diberi nama Corona Virus Disease (COVID19)..$^{22}$

Sejak penyebaran Covid-19 di Wuhan dan beberapa Negara di dunia serta di Indonesia, virus Corona-19 telah berdampak buruk terhadap kehidupan manusia yaitu menyebabkan kematian bagi pasien yang terkena Covid dalam kategori yang tidak dapat ditolong atau disembuhkan. Mereka yang meninggal karena penyebaran virus Covid-19 tentu tidak dapat disangkal. Oleh karena banyak yang meninggal karena Corona-19 maka Corona kemudian dijadikan sebagai musuh seluruh umat manusia di dunia. Corona menjadi musuh manusia karena mengancam bahkan menghilangkan nyawa manusia. Tentang akiabat buruk dari virus ini, situs CNN Indonesia memberitakan bahwa menurut penelitian para ahli penyakit menular memprediksi covid-19 dapat melenyapkan seseorang atau mengakibatkan kematian manusia pada angka 2,2 juta Amerika Serikat bila pemerintah tidak secara cepat mengambil langkah agresif untuk membendung penyebaran virus corona-19. ${ }^{23}$ Selian itu Perserikatan Bangsa-Bangsa atau disebut dengan Gedung Putih juga memandang Corona-19 sebagai musuh yang mengancam bahkan melenyapkan nyawa seseorang. Akibat buruk itu membuat "Gedung putih mengeluarkan larangan berkumpul lebih dari 10 orang sejak 18 Maret lalu. Namun, kebijakan itu tidak bersifat perintah, melainkan imbauan." 24

Pernyataan-pernyataan di atas jelas yaitu Corona Virus 2019 adalah musuh manusia. Oleh karena musuh maka setiap orang bahkan pemerintah berusaha untuk mencegah ancaman tersebut. Upaya itu perlu karena Covid dapat merengut nyawa seseorang. Dalam berita kompas.com tertanggal 25/7 2020 menyatakan "Tingkat Kematian akibat Covid-19 di DKI 4,1 Persen, Kesembuhan 63 Persen" dari jumlah pasien yaitu "dari 18.230 kasus Covid-19 di DKI, jumlah pasien yang meninggal adalah 755 orang."25 Untuk informasi terkini per 31 Agustus 2020 berdasarkan data dalam halaman worlddometers sebagaimana yang diberitakan dalam kompas.com pada tanggal 31 Agustus 2020 yaitu terdapat "25,3 juta kasus virus corona yang telah dikonfirmasi di dunia. Dari angka tersebut, 850.064 orang meninggal dunia, dan 17,7

22 Adityo Susilo dkk, Coronavirus Disease 2019: Tinjauan Literatur Terkini. https://ocw.ui.ac.id/pluginfile.php/2469/mod_resource/content/3/415-1924-1-PB.pdf.pdf (Dikasies tanggal, 1 September 2020)

23 Sikap Trump Lonjakan Virus Corona di AS. https://www.cnnindonesia.com/internasional/20200408151309-134-491686/sikap-trump-danlonjakan-virus-corona-di-as (Diakses tanggal 31 Agustus 2020)

24 Sikap Trump dan Lonjakan Virus Corona di AS. https://www.cnnindonesia.com/internasional/20200408151309-134-491686/sikap-trump-danlonjakan-virus-corona-di-as (Diakses tanggal 31 Agustus 2020)

25Tingkat Kematian akibat Covid-19 di DKI 4,1 Persen, Kesembuhan 63 Persen. https://megapolitan.kompas.com/read/2020/07/25/16080901/tingkat-kematian-akibat-covid-19-didki-41-persen-kesembuhan-63-persen (Diakses tanggal 31 Agustus 2020) 
juta pasien dinyatakan sembuh." 26 Dalam media online yang lain diberitakan bahwa mereka yang meninggal karena terkena penyebaran virus covid- 19 sebanyak 1.186 orang. ${ }^{27}$ Kemudian dalam situs Tribun Palu yang terbit secara online pada tanggal 30 Agustus 2020 memberi informasi yakni “... untuk pasien meninggal dunia bertambah sebanyak 82 korban, sehingga total menjadi 7.343 kasus kematian."28

Informasi di atas menegaskan bahwa penyebaran virus Covid-19 memang dipandang sebagai musuh karena merengut nyawa seseorang yang terserang virus ini, ada yang dapat disembuhkan tetapi ada pula yang sudah menjalani perawatan tetapi tidak dapat ditolong, akhirnya meninggal dunia. Dalam hal ini, kematian seseorang yang disebabkan karena penyebaran virus Corona menjadikan Covid-19 sebagai musuh seluruh manusia di dunia, khususnya para didaskalos di Sekolah Tinggi Teologi di Indonesia.

Corona-19 memang mengancam dan melenyapkan nyawa manusia. Dalam konteks demikian, Corona-19 dapat dipahami sebagai alat Tuhan dalam mengakhiri suatu kehidupan secara jasmani pada diri seseorang yang tidak disiplin dalam protokoler kesehatan. Penulis namakan alat Tuhan tidak bermaksud menyatakan bahwa Tuhan adalah sumber virus. Namun yang hendak penulis tegaskan disini yakni munculnya dan tersebarnya virus dapat dipandang secara teologis sebagai alat Tuhan untuk kehidupan jasmani seseorang yang tidak menaati hal-hal yang mesti dilakukan pada masa penyebaran virus. Misalnya berkemauan keras untuk berkumpul dengan orang lain dalam jumlah yang banyak, tidak menggunakan masker dll. Akibat ketidak taatan dalam protokoler keselamatan maka ada yang terserang virus dan menyebabkan kematian.

Agar supaya Corona-19 tidak melenyapkan nyawa maka para didaskalos melakukan sejumlah tindakan kesehatan seperti: cuci tangan dengan air mengalir, pakai masker ketika keluar rumah dan berada di tempat umum maupun tempat kerja, menjaga jarak social. Mengapa perlu melakukan prosedur kesehatan seperti ini? Jawabannya yakni virus ini mematikan karena menyerang sistem pernapasan manusia. Ketika Coronavirus menyerang (menular) pada seseorang maka akan terjadi beberapa gejala Klinis yaitu seseorang akan mengalami (1) demam, (2) Batuk, Pilek, (3) Letih, Lesu, (4) Sakit Tenggorokan, dan (5) gangguan (Sesak)Pernapasan. Sedangkan cara penularannya yaitu melalui tetesan cairan yang berasal dari batuk dan bersin, kontak pribadi seperti menyentuh dan berjabat tangan, menyentuh benda atau permukaan

26 Update Virus Corona Dunia 31 Agustus: 25,3 Juta Orang Terinfeksi | 78.000 Kasus Harian di India. https://www.kompas.com/tren/read/2020/08/31/073000965/update-virus-corona-dunia-31-agustus-25-3-juta-orang-terinfeksi-78.000?page=all (Diakses tanggal 31 Agustus 2020)

${ }^{27}$ Kasus Covid-19 Jakarta. https://corona.jakarta.go.id/id (Diakses tanggal 31 Agustus 2020)

28Sebaran Covid-19 Minggu 30 Agustus 2020 DKI Jakarta Catat Kasus Harian Terbanyak, 1.094 dalam $24 \mathrm{Jam} . \quad$ https://palu.tribunnews.com/2020/08/30/sebaran-covid-19-minggu-30-agustus-2020-dkijakarta-catat-kasus-harian-terbanyak-1094-dalam-24-jam (Diakses tanggal 31 Agustus 2020) 
dengan virus di atasnya, kemudian menyentuh mulut, hidung, atau mata sebelum mencuci tangan. ${ }^{29}$

Beberapa indikator dari penyebaran virus Covid-19 seperti yang disebutkan di atas menjadikan pengetahuan yang berharga dalam hal mengantisipasi penyebaran Covid19. Penyebaran Covid-19 memang demikian cepat mempengaruhi berbagai tempat di dunia termasuk Indonesia. Penyebaran tersebut membuat peningkatan jumlah pasien yang terkena Covid-19. Itulah sebabnya di beberapa wilayah di Indonesia diterapkan Pembatasan Sosial Berskala Besar (PSBB). Pemberlakuan PSBB kemudian diikuti dengan instruksi kerja dari rumah dan belajar-mengajar dari rumah serta ibadah dari rumah yang bertujuan untuk mencegah penyebaran virus Covid-19. Taman para didaskalos juga mengikuti PSPB yang ditetapkan pemerintah. Hal ini menandakan bahwa ada penyerangan Corona virus yang dapat saja memasuki Sekolah Tinggi Teologi. Memang ada yang menyatakan bahwa penyebaran dan daya tahan Covid-19 di suatu tempat seperti di suatu benda tidak dapat dipastikan. Namun virus ini dapat dibunuh dengan menggunakan disinfektan sederhana, membiasakan mencuci tangan dengan air dan sabun serta hindari menyentuh mata, mulut atau hidung. Cara ini dapat melindungi diri dari serangan Coronavirus-19. 30 Itulah sebabnya dalam kehidupan di Sekolah Tinggi Teologi, warganya menggunakan test suhu tubuh, memakai masker, mencuci tangan dan menjaga jarak ketika memasuki dan berada di kampus dan kantor STT.

Jadi, virus covid-19 dapat dipandang sebagai alat Tuhan dalam mengakhiri hidup seseorang secara jasmani bila seseorang tidak taat dalam prosedur kesehatan yang ditetapkan pihak berwewenang. Penekanan kematian jasmani itu penting agar pembaca tidak menghubungkan ke kematian kekal pada dunia yang akan datang sesuai iman Kristen.

\subsection{Covid-19 Sebagai Kawan (alat Tuhan memajukan Kreativitas dan Inovasi)}

Covid-19 memang dipandang sebagai musuh manusia yang bersifat lokal, nasional dan internasional. Dikatakan demikian karena Covid-19 dapat membunuh manusia tanpa bisa diadili oleh pengadilan manapun untuk kemudian dipenjarakan. Mengapa dipenjarakan? Karena Covid-19 adalah pembunuh manusia yang tidak mengikuti protokol kesehatan yang telah ditetapkan oleh pihak yang berwewenang secara nasional maupun internasional. Lalu mengapa sub judul ini berlawanan dengan

\footnotetext{
${ }^{29}$ Informasi Tentang Virus Corona (Novel Coronavirus). https://stoppneumonia.id/informasitentang-virus-corona-novel-coronavirus/

30Informasi Tentang Virus Corona (Novel Coronavirus). https://stoppneumonia.id/informasitentang-virus-corona-novel-coronavirus/
} 
konsep Covid -19 sebagai musuh. Ya bila dikatakan Covid sebagai kawan ${ }^{31}$ tidak bermaksud untuk mendorong seseorang bergaul dekat dengan Covid-19. Jadi yang penulis maksudkan dengan frasa Covid-19 sebagai kawan adalah menjadikan masa penyebaran ini sebagai masa di mana setiap orang mengembangkan hal-hal yang bersifat perubahan mendasar dan drastis. Misalnya dalam dunia pendidikan, kelas konvensional berubah menjadi kelas daring. Para didaskalos dapat mengajar dari rumah atau darimana saja asalkan ada alat-alat seperti handphone, laptop yang terkoneksi internet. Video conference yang biasanya tidak jarang dipakai dalam proses perkuliahan, kini setiap didaskalos harus berusaha untuk menggunakan video conference seperti menggunakan aplikasi zoom, Microsoft teams (ms teams), google meet, dan aplikasi lainnya. Hal-hal inilah yang penulis maksudkan dengan istilah 'Covid19 sebagai kawan'. Kawan dalam arti memandang Covid-19 dalam sisi positif.

Dalam paradigma sebagaimana yang penulis maksudkan di atas, sisi positif dari Covid-19 yaitu penyebaran virus Corona membuat didaskalos konvensional menjadi Didaskalolos Online (Daring). Perubahan ini menyebabkan para dosen dan mahasiswa melakukan pembelajaran secara daring. Para dosen teologi yang dulu bersifat konfensional sekarang bersifat online dalam memberi perkuliahan via video conference. Kelas menetap menjadi kelas dinamis dengan memanfaatkan media virtual (Online). Sebuah metode kuliah yang jarang dipakai pada zaman sebelum epidemic Covid-19, kini menjadi sebuah keharusan. Para didaskalos di Sekolah Tinggi Teologi wajib melakukan pengajaran secara online. Sebelum covid-19, para didaskalos mengajar di ruang kuliah dan bertatap muka dengan mahasiswa. Teknologi online sebenarnya sudah ada sebelum covid-19 hanya saja jarang dipakai oleh para didaskalos.

31 Penulis tidak memasukan ayat Alkitab ke dalam pembahasan tentang Covid-19 sebagai kawan. Hal ini penulis lakukan dalam kesadaran disiplin keilmuan. Dalam studi teologi ada istilah eksegesis dan eisagesis. Penulis tidak boleh membaca kedalam teks tetapi harus membaca keluar dari teks Alkitab. Ya dalam Alkitab tidak disebutkan Covid-19. Namun kawan yang setara dengan Covid-19 disaksikan dalam Alkitab misalnya Alkitab menyebutkan roh yang menyeret seorang anak ke dalam api atau air untuk membinasakan sang anak (Markus 9:22). Ayat ini tidak disamakan dengan Covid-19 yang juga mematikan. Covid-19 sebagai kawan dapat dihubungkan dengan kasus orang buta sejak lahir dalam Yohanes 9:1-41. Buta sejak lahir dapat dipandang sebagai kawan karena melaluinya karya Allah dinyatakan. Tetapi penulis tidak memasukan dalam pembahasan untuk menghindari usaha membaca ke dalam teks Alkitab. Siloam juga menjadi Kawan bagi orang buta sejak lahir. Ya tentu Yesus adalah kawan sejati. Jadi, penulis tidak memasukan ayat Alkitab dalam membahas Covid-19 karena Alkitab bukan kitab Covid-19 yang memudahkan untuk secara gamblang penulis menemukan ayat Alkitab tentang Covid-19, apalagi covid sebagai kawan. Namun makna kata Covid-19 sebagai kawan tentunya sudah jelas. Karena Covid-19 orang marak menggunakan video conference untuk mengajar. Sementara pada Zaman Yesus belum ada penyebaran Covid-19. Walaupun begitu, Yesus juga menggunakan teknologi sederhana untuk mengajar seperti Yesus menggunakan perahu untuk mengajar (Luk.5:3). Perahu adalah hasil tekne dan logi manusia (perpaduan pikiran dan seni). Artinya perahu adalah hasil berpikir dan usaha manusia. Usaha membentuk perahu membutuhkan berpikir dan seni membentuk bahan-bahan menjadi sebuah perahu. Demikian juga video conference adalah bagian dari teknologi manusia yang dipakai para didaskalos walaupun para didaskalos belum pernah mendoakan mereka yang menggunakan pikiran untuk menemukan video konferensi. Namun hasil karya mereka dipakai oleh para didaskalos. 


\section{Definisi Konseptual dan operasional}

Definisi ini merupakan kesimpulan penulis yang terinspirasi dari kajian teori atas pokok yang diteliti. Definisi ini berguna untuk penetapan instrument penelitian baik secara kualitatif maupun kuantitatif.

Jadi, yang penulis maksudkan dengan judul penelitian "Ketika Covid-19 Menyerang Taman Didaskalos" adalah penyebaran Covid-19 yang dapat masuk ke taman didaskalos (kampus Sekolah Tinggi Teologi) bila tidak diantisipasi dengan kesiapan warga didaskalos (para dosen dan mahasiswa) dengan dimensi menjaga prosedur kesehatan yang ditetapkan pihak berwewenang dengan indikator: test suhu tubuh, menggunakan masker, cuci tangan dan menjaga jarak social; dimensi perubahan interaksi didaskalos dalam proses pembelajaran dengan indicator: kelas konfensional ke online Mengajar dan belajar dari rumah, pemanfaatan teknologi video conference, rekaman video pembelajaran; dimensi Covid-19 sebagai musuh manusia dengan indikator: mengganggu kesehatan tubuh manusia dan mengakibatkan kematian; Covid19 sebagai kawan dengan indikator: melek online, mengajar dan belajar dari mana saja.

\section{Temuan Penelitian dan pembahasan ${ }^{32}$}

\begin{tabular}{|l|l|l|}
\hline $\begin{array}{l}\text { Nomor } \\
\text { Domain }\end{array}$ & $\begin{array}{c}\text { Data Kuantitatif Serbuan } \\
\text { Covid-19 ke } \\
\text { Taman Didaskalos }\end{array}$ & Domain dan Analisis Domain \\
\hline 1 & $\begin{array}{l}\text { Hasil pengamatan dan } \\
\text { wawancara ketaatan } \\
\text { didaskalos dalam } \\
\text { protokoler kesehatan } \\
\text { (Prokes) Covid-19 }\end{array}$ & $\begin{array}{l}\text { Domain Didaskalos } \\
\text { 1. Calon Didaskalos. Domain untuk calon } \\
\text { didaskalos juga dibagi lagi dalam domain } \\
\text { berdasarkan semester (I, V dan VIII). } \\
\text { Dari keseluruhan calon pendidik Kristen } \\
\text { berjumlah } 67 \text { orang. Berdasarkan pengamatan }\end{array}$ \\
\hline
\end{tabular}

32 Penelitian ini jelas adalah penelitian kualitatif dengan mengadakan penelitian lapangan. Dalam metodologi sudah disebutkan bahwa metode penelitian yang dipakai adalah penelitian kualitatif. Penulis juga menyebutkan analisis data yang dipakai yaitu taksonomi domain. Jadi dalam metodologi sudah jelas bahwa penelitian ini menggabungkan penelitian teoritik (kajian pustaka) dan empiris (penelitian lapangan). Sedangkan locus dalam arti tempat yaitu di Sekolah Tinggi Teologi IKSM Santosa Asih. Lokus juga tidak pernah dihubungkan dengan mereka yang dijadikan sebagai responden dalam penelitian. Pengamatan dilakukan di STT IKSM Santosa Asih sejak terjadinya Covid-19 di Jakarta dan pemberlakuan PSBB di Jakarta. Dalam hal ini peneliti sebagai orang dalam di locus atau tempat penelitian paham tentang prosedur kesehatan yang diberlakukan di kampus yang dijadikan sebagai tempat penelitian.Selain pengamatan, penulis juga menggunakan wawancara dengan perwakilan semester. Penggunaan instrument ini disebabkan karena penulis adalah instrument kunci dalam metodologi penelitian kualitatif. Oleh karena penulis adalah instrument kunci maka alat mengumpulkan data dapat dipakai secara variatif seperti menggunakan pengamatan dan wawancara. Pengambilan gambar tidak dilakukan karena akan mengambil tempat yang besar dalam artikel ini. 


\begin{tabular}{|c|c|c|}
\hline & & $\begin{array}{l}\text { dan wawancara dengan perwakilan domain } \\
\text { atau semester yaitu Semester I, V dan VII } \\
\text { bahwa mereka disiplin dalam mengikuti } \\
\text { protokol kesehatan seperti menggunakan } \\
\text { masker saat berada dalam perkumpulan, } \\
\text { menjaga jarak, mencuci tangan. Selain itu } \\
\text { secara empiris ditemukan bahwa tempat } \\
\text { duduk seperti sofa di Lobi Kampus, Kantin } \\
\text { Kampus juga mengikuti protokoler kesehatan } \\
\text { dengan indikator kursi tertentu diberi tanda } \\
\text { silang (larangan) } \\
\text { Domain Didaskalos pejabat struktural. } \\
\text { Domain ini dapat dikembangkan lagi menjadi } \\
\text { domain SESTI yang terdiri dari Ketua, Wakil } \\
\text { Ketua I-III. Domain berikutnya yakni Staf. } \\
\text { Total sebanyak } 11 \text { orang. Mereka juga disiplin } \\
\text { dalam protokol kesehatan seperti memakai } \\
\text { masker saat memasuki kantor dan bekerja } \\
\text { selama jam kerja pukul 08.00-17.00. Selain itu } \\
\text { mereka mencuci tangan di tempat yang sudah } \\
\text { disediakan pihak penyelenggara di halaman } \\
\text { kampus. Para didaskalos juga menjaga jarak } \\
\text { saat berkumpul. Ketaatan ini menyebabkan } \\
\text { para didaskalos tidak terpapar virus Corona- } \\
\text { 19. }\end{array}$ \\
\hline 2 & $\begin{array}{l}\text { Hasil pengamatan dan } \\
\text { wawancara dengan para } \\
\text { didaskalos tentang Covid- } \\
19 \text { sebagai musuh } \\
\text { (Menyebabkan } \\
\text { kematian) }\end{array}$ & $\begin{array}{l}\text { Belum ada calon didaskalos dan didaskalos yang } \\
\text { meninggal karena Covid. Calon didaskalos dan } \\
\text { didaskalos mengetahui bahwa Covid-19 adalah } \\
\text { musuh yang dapat mengakibatkan kematian. }\end{array}$ \\
\hline 3 & $\begin{array}{l}\text { Hasil pengamatan dan } \\
\text { wawancara dengan para } \\
\text { didaskalos tentang Covid } \\
\text { sebagai kawan }\end{array}$ & $\begin{array}{l}\text { Calon didaskalos Belajar online melalui video } \\
\text { conference } \\
\text { Para Didaskalos mengajar dari rumah secara } \\
\text { online melalui beberapa aplikasi video conference } \\
\text { seperti zoom, google meet. Dari kedua aplikasi ini, } \\
\text { berdasarkan pengamatan penulis di WA Group } \\
\text { untuk Semester V dan VII lebih banyak }\end{array}$ \\
\hline
\end{tabular}




\begin{tabular}{|l|l|}
\hline menggunakan google meet. Pemanfaatan aplikasi \\
ini sebelum merebaknya Covid-19, belum ada \\
dosen yang menggunakannya Kuliah online \\
hanya sebatas memanfaatkan blog dan website \\
seperti mediailmiah.com untuk pembelajaran \\
online. Setelah terjadi penyebaran Covid-19 maka \\
seluruh didaskalos (para dosen dan mahasiswa) \\
mulai menggunakan video conference untuk \\
pembelajaran. Disini Nampak bahwa Covid-19 \\
dapat dipandang dari sisi positif (kawan) untuk \\
memacu para didaskalos menggunakan peta dan \\
gambar Allah dalam dirinya untuk menggunakan \\
teknologi online untuk keperluan pembelajaran. \\
Para dosen mengajar dari rumah. Tentu ada \\
efisiensi anggaran yaitu transportasi ke kampus. \\
Pada masa pandemic covid-19 ini para dosen \\
dapat mengajar dari rumah ke beberapa kampus \\
seperti yang terjadi pada penulis. Dari rumah \\
mengajar ke kampus Sekolah Tinggi Teologi IKSM \\
Santosa Asih, mengajar di Universitas Kristen \\
Indonesia, Mengajar di Sekolah Tinggi Pelita \\
Dunia, dan Sekolah Tinggi Teologi Hagiasmos \\
Mission yang semuanya berlangsung secara \\
online dan dimulai dari rumah. Inilah yang \\
dimaksudkan dengan Covid-19 sebagai kawan. \\
Kawan dalam arti munculnya Covid-19 dan \\
penyebarannya memaksa para didaskalos untuk \\
kreatif dan inovatif dalam bidang pengajaran.
\end{tabular}

\section{Kesimpulan}

Ketika Covid-19 menyerbu Taman Didaskalos, para didaskalos di Sekolah Tinggi Teologi IKSM Santosa Asih mengantisipasinya dengan cara menjaga diri sesuai protokoler kesehatan seperti menggunakan masker, mencuci tangan, menjaga jarak social dan mengajar online dari rumah melalui aplikasi video conference agar Covid sebagai musuh tidak melenyapkan nyawa para didaskalos. Selain itu para didaskalos merespon serbuan Covid-19 ke taman didaskalos dengan paradigma bahwa ada sisi positif yaitu Covid-19 memaksa para didaskalos melek teknologi online dalam melakukan perintah Tuhan dalam hal mengajar. Instrusksi mengajar seperti ini 
disebutkan dalam Matius 28:20. Para didaskalos memandang Covid dalam sisi negative (maut) dan positif (alat Tuhan) untuk memaksa warga didaskalos untuk berteknologi (konsep) dan memanfaatkan alat secara baik dalam menunjang proses pembelajaran secara efisien.

\section{Referensi}

Afrizal, Metode Penelitian Kualitatif Sebuah Upaya Mendukung Penggunaan Penelitian Kualitatif Dalam Berbagai Disiplin Ilmu (Jakarta: Raja Grafindo Persada, 2016)

Daud, Anwar Daud, dkk. Penanganan Coronavirus (Covid-19) Ditinjau dari Perspektif Kesehatan Masyarakat (Yogyakarta : Gosyen Publishing, 2020), 1

Hermina P (Ed), Pemanfaatan Blog Untuk Media Pembelajaran Alternatif (Yogyakarta: Wahana Komputer dan Andi, 2013)

Holmes, Arthur F. Segala Kebenaran adalah Kebenaran Allah (Surabaya: Momentum, 2009)

Homrighausen , E.G. dan Enklaar , I.H. Pendidikan Agama Kristen (Jakarta : BPK, 2015)

Indriantoro, Nur dan Supomo, Bambang., Metodologi Penelitian Bisnis Untuk Akuntansi dan Manajemen (Yogyakarta: BPFE Yogyakarta, 2002)

Johnston, Philip. IVP Introduction to thr Bible. Pengantar untuk Mengenal Alkitab.

Memahami Alkitab Berdasarkan Sejarah, Tema dan Penafsirannya (Bandung : Kalam Hidup, 2006)

Kristanto, Purnawan, Blog Gospel (Jakarta : BPK Gunung Mulia, 2010), 3

Permana, Lucky. Membuat website professional dengan Blogspot (Jakarta : Elex Media Komptindo, 2011)

Piaget, Jean. (disunting Agus Cremers), Antara Tindakan dan Pikiran (Jakarta : Gramedia, 1988)

Sasmoko, Metodologi Penelitian (Jakarta: FKIP UKI dan PPS, 2004)

Subagyo, Andreas. Pengantar Riset Kuantitatif dan Kualitatif Termasuk Riset Teologi dan Keagamaan (Bandung: Kalam Hidup, 2004)

Tomatala, Yakob. Pembimbing Logika Seni Berpikir Benar, Baik, Cermat, Cerdas, Cerdik, Jitu dan Unggul (Jakarta : Media Penerbit Kristen YT Leadership Foundation, 2008)

http://repository.upi.edu/10773/4/t_pk_0909570_chapter3.pdf 
Virus. https://id.wikipedia.org/wiki/Virus (Diakses tanggal 07/09 2020)

Patogen. https://id.wikipedia.org/wiki/Patogen (Diakses tanggal 08/09 2020)

Episteme, https://en.m.wikipedia.org/wiki/Episteme, (Diakses tanggal 08/09 2020)

Virus Corona. https://www.alodokter.com/virus-corona (Diakses tanggal 08/09 2020)

Virus Corona. https://www.alodokter.com/virus-corona (Diakses tanggal 08/09 2020)

Adityo Susilo dkk, Coronavirus Disease 2019: Tinjauan Literatur Terkini.

https://ocw.ui.ac.id/pluginfile.php/2469/mod_resource/content/3/415-1924-1-

PB.pdf.pdf (Dikasies tanggal, 1 September 2020)

Kronologi Munculnya Covid-19 di Indonesia hingga Terbit Keppres Darurat Kesehatan.

https://www.merdeka.com/trending/kronologi-munculnya-covid-19-di-indonesiahingga-terbit-keppres-darurat-kesehatan-kln.html (Diakses tanggal 08/09 2020)

Adityo Susilo dkk, Coronavirus Disease 2019: Tinjauan Literatur Terkini.

https://ocw.ui.ac.id/pluginfile.php/2469/mod_resource/content/3/415-1924-1-

PB.pdf.pdf (Dikasies tanggal, 1 September 2020)

Sikap Trump dan Lonjakan Virus Corona di AS.

https://www.cnnindonesia.com/internasional/20200408151309-134-

491686/sikap-trump-dan-lonjakan-virus-corona-di-as (Diakses tanggal 31 Agustus 2020)

Tingkat Kematian akibat Covid-19 di DKI 4,1 Persen, Kesembuhan 63 Persen.

https://megapolitan.kompas.com/read/2020/07/25/16080901/tingkat-kematianakibat-covid-19-di-dki-41-persen-kesembuhan-63-persen (Diakses tanggal 31

Agustus 2020)

Update Virus Corona Dunia 31 Agustus: 25,3 Juta Orang Terinfeksi | 78.000 Kasus Harian di India.

https://www.kompas.com/tren/read/2020/08/31/073000965/update-viruscorona-dunia-31-agustus--25-3-juta-orang-terinfeksi-78.000?page=all (Diakses tanggal 31 Agustus 2020)

Kasus Covid-19 Jakarta. https://corona.jakarta.go.id/id (Diakses tanggal 31 Agustus 2020)

Sebaran Covid-19 Minggu 30 Agustus 2020 DKI Jakarta Catat Kasus Harian Terbanyak, 1.094 dalam 24 Jam. https://palu.tribunnews.com/2020/08/30/sebaran-covid-19- 
minggu-30-agustus-2020-dki-jakarta-catat-kasus-harian-terbanyak-1094-dalam24-jam (Diakses tanggal 31 Agustus 2020)

https://id.wikipedia.org/wiki/Virus (Diakses tanggal 07/09 2020)

Didaskalos.

https://www.blueletterbible.org/lang/lexicon/lexicon.cfm?t=kjv\&strongs=g1320

Diakses tanggal, 26 September 2020

Didaskalos. https://en.wiktionary.org/wiki/ $\delta\llcorner\delta \alpha ́ \sigma \kappa \alpha \lambda o \varsigma$ Diakses tanggal, 26

September 2020

Didaskalos. https://encyclopedia2.thefreedictionary.com/Didaskalos. Diakses tanggal, 26 September 2020

Bible Tools. Strong's \#1320: didaskalos (pronounced did-as'-kal-os) from 1321; an instructor (genitive case or specially):--doctor, master, teacher.

https://www.bibletools.org/index.cfm/fuseaction/Lexicon.show/ID/G1320/didask alos.htm. Diakses tanggal, 26 September 2020

Didaskalos, https://alkitab.sabda.org/strong.php?id=1320 (Diakses tanggal, 29 Agustus 2020)

Informasi Tentang Virus Corona (Novel Coronavirus). https://stoppneumonia.id/informasi-tentang-virus-corona-novel-coronavirus/

Anies Memperpanjang PSBB Transisi hingga 10 September 2020.

https://megapolitan.kompas.com/read/2020/08/28/05542191/anies-

memperpanjang-psbb-transisi-hingga-10-september-2020 (Diakses tanggal 29

Agustus 2020)

Yonas Muanley. Profil Google Scholar.

https://scholar.google.co.id/citations?hl=id\&user=u_9MeLcAAAAJ (diakses tanggal, 29 Agustus 2020).

Idarman, wawancara oleh Penulis, Jakarta, Indonesia, 1 Oktorber 2020

Kefin Kristian Ginting, Wawancara oleh penulis, Jakarta, Indonesia, 1 Oktober 2020

Maato, Wawancara oleh penulis, Jakarta, Indonesia, 1 Oktober 2020

Artikan Zega, Wawancara oleh penulis, Jakarta, Indonesia, 1 Oktober 2020 